\title{
Sociabilidad y cultura en los centros de trabajadores Tucumán, Argentina, (1897-1916)
}

Vanesa Teitelbaum

(ISES/CONICET)

Argentina

Recibido: abril de 2014

Aprobado: agosto de 2014

Resumen: Desde una perspectiva de historia social, abierta a su vez a los fenómenos culturales y políticos, esta contribución analiza las prácticas de sociabilidad y de cultura desarrolladas por los trabajadores, mayoritariamente de oficio, a través de centros obreros, gremios y mutuales que se formaron en Tucumán entre 1897 y 1916. En particular, la investigación explora las veladas literario-musicales destinadas a recaudar fondos y conmemorar efemérides destacadas del calendario patrio y asociativo. Paralelamente, examina las manifestaciones del Primero de Mayo, entendidas como la principal conmemoración obrera. Se argumenta que las fronteras de las sociedades fueron porosas y, en la práctica asociacionista, las funciones genéricas de las mutuales, gremios y sociedades de resistencia podían combinarse con propósitos orientados a estimular la educación, la sociabilidad, el recreo y la cultura de los trabajadores.

Palabras claves: conferencias, fiestas, manifestaciones, socialistas, anarquistas.

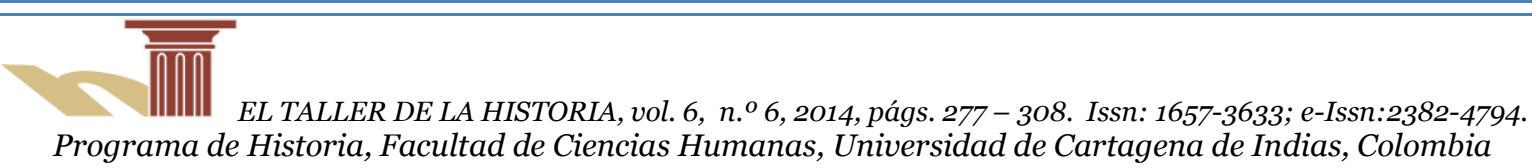




\section{Sociability and culture in workers centers Tucumán, Argentina, (1897-1916)}

Abstract: This paper analyzes social and cultural practices by workers (mostly skilled workers) through worker centers, unions and mutualities that formed in Tucumán between 1897 and 1916) from the perspective of a Social History which is permeable to cultural and political phenomena. In particular, the research explores the literary and musical events intended to raise funds and to celebrate significant national holidays and unions' events. Meanwhile, is examines the May Day rallies, which are believed to be the most important workers' celebration. It is argued that societies' boundaries were porous, and in associative practice, the general role of mutualities, unions and resistance societies could be combined for purposes intended to encourage workers' education, sociability, recreation and culture.

Key words: conferences, parties, demonstrations, socialists, anarchists.

\section{Presentación}

Hacia 1890, en Tucumán, en consonancia con el avance de la industrialización basada en la especialización azucarera y los procesos de modernización de la infraestructura urbana e innovación tecnológica y de las comunicaciones que, sin embargo, no se extendían por igual en todo el espacio provincial, adquirió mayor impulso la formación de mutuales, salas de lectura, bibliotecas, clubes sociales, centros políticos y asociaciones deportivas que buscaban dar respuesta a las necesidades vinculadas con la atención de la salud y la cobertura ante el fallecimiento, los propósitos de índole cultural y educativa, los intereses partidarios y el afán por participar de espacios de esparcimiento y disfrute del tiempo libre. A pesar de los objetivos genéricos que distinguían a las sociedades, en la práctica asociacionista las fronteras no fueron tan rígidas $\mathrm{y},{ }^{1}$ así por ejemplo, existieron sociedades mutuales que además de llevar adelante las tareas referidas al socorro desarrollaron eventos de naturaleza cultural, recreativa y educativa, al impulsar proyectos para la edificación de bibliotecas, encabezar fiestas y veladas literario-musicales, dictar conferencias, etc. ${ }^{2}$ Asi-

1 Maurice Agulhon, El Círculo burgués. La sociabilidad en Francia, 1810-1848, Buenos Aires, Siglo XXI Eds., 2009, p.43.

2 Con lo cual, muchas mutuales funcionaron también como asociaciones sociales, culturales, educativas y recreativas (Jürgen Kocka, "Los artesanos, los trabajadores y el Estado: hacia una historia social de los comienzos del movimiento obrero alemán”, en Historia Social n. ${ }^{\circ} 12$, Valencia, Centro 
mismo, algunas sociedades de resistencia motorizaron actividades recreativas, como bailes, destinados a atraer a los trabajadores a las asociaciones, lo cual generó tensiones entre los dirigentes obreros, sobre todo entre los anarquistas convencidos que dichas expresiones frenaban el avance de la lucha obrera y, por esa vía, alteraban el verdadero fin de las sociedades de resistencia. ${ }^{3}$ Finalmente, hubo gremios que contemplaron labores mutuales y sociedades de socorro mutuo que apoyaron la protesta obrera, evidencia de la complementariedad posible entre las dos facetas del activismo obrero, la mutual y la gremial.

Para desarrollar estas hipótesis, el trabajo examina la sociabilidad de los trabajadores, mayoritariamente de oficio, a través de los centros obreros, gremios y mutuales formados en la ciudad de San Miguel de Tucumán -capital y centro comercial y administrativo de la provincia- y en las principales localidades del interior como Monteros y Aguilares, en un periodo comprendido, aproximadamente, entre 1897 y 1916. Más particularmente, la investigación indaga las veladas literario-musicales y bailes destinados a recaudar fondos y conmemorar efemérides destacadas del calendario patrio o asociativo y ahonda en las manifestaciones del Primero de Mayo, entendidas como la principal conmemoración obrera.

Planteado desde una perspectiva de historia social, abierta a su vez a los fenómenos culturales y políticos, el estudio se basa fundamentalmente en una metodología cualitativa para explorar un conjunto de fuentes. En particular, revisamos para los años 1897-1916, El Orden, principal diario de Tucumán durante la época estudiada. Desde 1912 -año en que se fundó- a 1916, consultamos La Gaceta, que gradualmente asumió gran protagonismo en el escenario regional del Norte argentino. Además, contamos con los datos obtenidos de periódicos hasta ahora inexplorados como El Nacional y La Estrella del Norte, semanario liberal que se proclamaba defensor de la clase trabajadora y sobre el cual hasta ahora no se tenía ninguna noticia. También, examinamos la prensa gremial y obrera, al localizar El Tipógrafo, para 1907, y Germinal, publicación anarquista editada en 1908 como un

de la UNED/Instituto de Historia Social/Fundación Historia Social, 1992, pp.101-118, e Hilda Sabato, "Capítulo 2/1860-1920, Estado y sociedad civil”, en Elba Luna y Elida Cecconi (coords.), De las cofradías a las organizaciones de la sociedad civil. Historia de la iniciativa asociativa en Argentina, 1776-199o, Buenos Aires, Edilab Editora, 2002, pp.99-167.

3 Ricardo Falcón, El mundo del trabajo urbano (189o-1914), Buenos Aires, Centro Editor de América Latina, 1986, pp.91-92. 
número único. ${ }^{4}$ A nivel nacional, recurrimos a La Vanguardia, órgano oficial del socialismo en Argentina, para la etapa comprendida entre 1897 y 1908 aproximadamente. 5

Las temáticas abordadas en esta contribución recuperan la noción de centros obreros como ámbitos apropiados para fomentar la interacción con los otros mediante el disfrute del tiempo libre, el estímulo a la educación, la cultura, la solidaridad y las redes sociales, tal como sugiere Manuel Morales Muñoz en su análisis sobre el caso español. En esa tónica, el autor propone que los centros obreros podían favorecer el aprendizaje de valores y hábitos, propiciar la conformación de identidades grupales y, en algunos casos, contribuían a atender los reclamos sociales y laborales. ${ }^{6}$

En gran medida, dicha perspectiva reconoce la influencia de análisis pioneros como los de Edward P. Thompson y Eric Hobsbawm, quienes desempeñaron un papel clave en la renovación de la historia social, ya que abordaron problemáticas poco exploradas hasta entonces, como las fiestas y ritos obreros, los tiempos del trabajo y del ocio, el papel de los espacios y las formas de sociabilidad. Por esa vía, la historiografía marxista británica trascendía los límites que habían caracterizado hasta entonces a los estudios sobre el movimiento obrero circunscripto al análisis de las temáticas ideológicas y políticas y al examen del funcionamiento interno de

4 Agradezco a María Fernández de Ullivary el facilitarme Germinal.

5 Otros materiales fundamentales para esta investigación fueron los expedientes de archivo, como los resguardados en el Archivo Histórico de Tucumán (en adelante AHT), especialmente en la Sección Administrativa (en adelante SA) que contiene solicitudes de reconocimiento jurídico, reglamentos, estatutos y comunicaciones entabladas entre las mutuales de trabajadores y el gobierno. Un repositorio documental esencial fue, también, la Biblioteca Popular Obrera "María Luisa Buffo de Ferro" (en adelante BPO. BF), de Monteros (Tucumán), donde localizamos documentos --hasta ahora inexplorados-- pertenecientes el Centro de Trabajadores de Socorros Mutuos de Obreros, creado en Monteros en 1899 y que alcanzó una notable proyección en el tiempo. Dicho corpus documental incluye libros de sesiones de comisiones directivas, actas de asambleas generales y extraordinarias y diversas carpetas que reúnen correspondencia, artículos de prensa, cartas de socios y documentación interna del Centro.

6 Manuel Morales Muñoz, "Un espacio propio. Sociabilidad e identidad obrera en Andalucía”, en Historia Social, n. ${ }^{\circ}$ 56, Valencia, Centro de la UNED/Instituto de Historia Social, 2006, pp.53-69 y "Los trabajadores de oficio en la construcción del socialismo español", en Vicent Sanz Rosalén y José Antonio Piqueras (coords.), En el nombre del oficio. El trabajador especializado: corporativismo, adaptación y protesta, Madrid, Biblioteca Nueva, 2005. 
las organizaciones obreras y de las relaciones entre dirigentes y militantes a través de la revisión exclusiva de reglamentos y resoluciones de congresos. ${ }^{7}$

En el ámbito argentino el surgimiento de los estudios sobre trabajadores recorrió una trayectoria similar e, inicialmente, las prácticas y discursos del movimiento obrero, sus luchas, reclamos y líderes fueron los aspectos privilegiados, sobre todo por aquellos militantes interesados en narrar los acontecimientos en los cuales habían intervenido o de los cuales formaron parte como testigos. ${ }^{8}$ Esta relevancia asignada al examen de los trabajadores organizados se conservó en los estudios posteriores --el grueso de los cuales fue publicado en la década de 1950-- que hicieron especial hincapié en la descripción y reconstrucción de las organizaciones gremiales, los congresos obreros y las gestas de lucha proletaria. ${ }^{9}$

Posteriormente, al calor de la renovación historiográfica alentada en particular por las contribuciones de la historia socio-económica y de otras ciencias humanas y sociales entre los años 1980 y 1990 emergieron aportes novedosos orientados a desentrañar las experiencias propias de los trabajadores en la fábrica, explicar la organización de los procesos de trabajo y dilucidar al sentido del espacio físico, re-

7 M. Morales Muñoz, "Un espacio propio", pp.53 y 54. Algunos aportes centrales originados en la historiografía marxista británica son, sin duda, George Rudé, La multitud en la historia. Los disturbios populares en Francia e Inglaterra, 1730-1848, Madrid, Siglo XXI, 1979, y Revuelta popular y conciencia de clase, Barcelona, Crítica/Grijalbo, 1981; Eric Hobsbawm y George Rudé, Revolución Industrial y revuelta agraria. El capitán Swing, Madrid, Siglo XXI, 1978; Eric Hobsbawm, Gente poco corriente. Resistencia, rebelión y jazz, Barcelona, Crítica, 1999; Edward P. Thompson, La formación de la clase obrera en Inglaterra tomo1, Barcelona, Editorial Crítica, 1989, y Tradición, revuelta y conciencia de clase, Estudios sobre la crisis de la sociedad preindustrial, Barcelona, Crítica, 1979.

8 Según Leandro Gutiérrez y Luis Alberto Romero esta perspectiva puede ejemplificarse para el caso argentino con los trabajos de Abad de Santillán, Sebastián Marrotta, Jacinto Oddone y Ruben Iscaro, cuyas filiaciones respectivas con el anarquismo, el socialismo, el sindicalismo y el comunismo impulsaron narraciones caracterizadas por el objetivo de justificar una cierta línea política. "Los sectores populares y el movimiento obrero: un balance historiográfico", en Leandro H. Gutiérrez y Luis Alberto Romero, Sectores populares, cultura y política. Buenos Aires en la entreguerra, Buenos Aires, Sudamericana, 1995. Una valoración diferente y más favorable sobre estos trabajos la realiza en su balance sobre la historia de los trabajadores Nicolás Iñigo Carrera, "La historia de los trabajadores”, en Jorge Gelman (comp.), La historia económica en la encrucijada, Buenos Aires, Prometeo, 2006.

9 Seguimos las consideraciones de Mirta Lobato y Juan Suriano, "Trabajadores y movimiento obrero: entre la crisis y la profesionalización del historiador", en Entrepasados año III, n. ${ }^{\circ} 4-5$, Buenos Aires, Universidad de Buenos Aires, 1993, pp.41-64. 
velador de las relaciones sociales. ${ }^{10}$ En función de estas preocupaciones, cobraron impulso también las experiencias de asociación, cultura y protesta de los trabajadores, temáticas especialmente trabajadas por Ricardo Falcón, Juan Suriano, Mirta Lobato y Enrique Mases, aportes insoslayables para esta investigación. ${ }^{11}$

En Tucumán, debido a la importancia que alcanzó la agroindustria azucarera, en especial a partir de 1880, los estudios sobre el mundo del trabajo y los trabajadores priorizaron el estudio de los peones y jornaleros del azúcar, sus condiciones de vida y estrategias de resistencia para enfrentar el sistema coactivo que dominó las relaciones labores en los ingenios hasta mediados de la década de $1890 .{ }^{12} \mathrm{Para}$ el periodo posterior y hasta aproximadamente los años 1920, las investigaciones sobre trabajadores quedaron como una materia pendiente, la cual comenzó a ser subsanada con los trabajos pioneros de María Celia Bravo sobre la cuestión social y la huelga de azucarera de 1904. ${ }^{13} \mathrm{~A}$ su vez, hace algunos años iniciamos una línea de investigación sobre reformadores sociales y mundo del trabajo en Tucumán entre 1890 y $1925 \cdot{ }^{14} \mathrm{El}$ presente estudio se inscribe en esta perspectiva y busca avanzar en

$10 \mathrm{Al}$ respecto, Juan Carlos Torre, "Acerca de los estudios sobre la historia de los trabajadores en Argentina”, en Anuario IEHS n. ${ }^{\circ} \mathrm{V}$, Tandil, Instituto de Estudios Histórico-Sociales, Facultad de Ciencias Humanas, Universidad Nacional del Centro, 1990.

11 Ricardo Falcón, Los orígenes del movimiento obrero (1857-1899), Buenos Aires, Centro Editor de América Latina, 1984; El mundo del trabajo urbano (189o-1914) y La Barcelona Argentina, Rosario, Laborde editor, 2005; Juan Suriano, Anarquistas. Cultura y política libertaria en Buenos Aires, 1890-1910, Buenos Aires, Ediciones Manantial, 2001; Mirta Lobato, La prensa obrera, Buenos Aires, Edhasa, Temas de la Argentina, 2009, p.175; Mirta Lobato y Silvana Palermo, "Del trabajo a las calles: dignidad, respeto y derechos para los y las trabajadoras", en Mirta Lobato (ed.), Buenos Aires. Manifestaciones, fiestas y rituales en el siglo XX, Buenos Aires, Biblos, 2011, pp.45-74; Enrique Mases, "El tiempo libre de los trabajadores en la norpatagonia. De la cultura política, las prácticas recreativas y deportivas al disciplinamiento social 1900-1945”, en Quinto Sol nº9-10, Santa Rosa, Universidad Nacional de La Pampa, 2005-2006, pp.73-97. Para otros periodos, contamos, por ejemplo, con el libro de Hernán Camarero, A la conquista de la clase obrera. Los comunistas y el mundo del trabajo en la Argentina, 1920-1935, Buenos Aires, Siglo XXI, 2007.

12 Daniel Campi, "Captación forzada de mano de obra y trabajo asalariado en Tucumán, 18561896", en Anuario IEHS n. ${ }^{\circ}$, Buenos Aires, Universidad Nacional del Centro de la Provincia de Buenos Aires, 1993; y Azúcar y trabajo. Coacción y mercado laboral. Tucumán, 1856-1896, Tesis doctoral (Inédita), Universidad Complutense de Madrid, 2002.

13 María Celia Bravo, "Liberales, Socialistas, Iglesia y Patrones frente a la situación de los Trabajadores en Tucumán (1880-1910)”, en Juan Suriano (comp.), La cuestión social en Argentina, 18701943, Buenos Aires, La Colmena, 2004, pp.31-61.

14 Algunos resultados obtenidos en esta línea se expusieron en María Celia Bravo y Vanesa Teitelbaum, "Socialistas y católicos disputando el mundo los trabajadores. Protesta, sociabilidad y política 
el estudio del asociacionismo laboral tucumano a través de una explicación sobre las expresiones de sociabilidad de los trabajadores.

Antes de comenzar el análisis propiamente dicho conviene indicar quiénes conformaban el mundo del trabajo tucumano en la época estudiada. Sin duda, un segmento fundamental del mercado laboral eran los peones y jornaleros del azúcar ocupados en los numerosos ingenios azucareros establecidos en la provincia, especialmente en Cruz Alta, principal Departamento azucarero, y en las fábricas de azúcar y de alcohol que funcionaban en el Distrito Capital, que si bien contaban con poca capacidad productiva ocupaban a un significativo número de peones. ${ }^{15}$

El cultivo y la comercialización de la caña de azúcar alentaron, a su vez, el desarrollo de actividades comerciales y de servicio, especialmente en la capital de la provincia, la ciudad de San Miguel de Tucumán, en donde un amplio y heterogéneo sector de trabajadores de oficio compuesto por albañiles, carpinteros, panaderos, sastres, herreros, fundidores, cocineros, licoreros y hojalateros, entre otros, caracterizaban la vida de la ciudad entre finales del siglo XIX y comienzos del Xx. Además, los procesos de crecimiento económico y de modernización de la infraestructura urbanización fomentaron el incremento del comercio y el transporte, propiciando el aumento de dependientes de comercio, de ferroviarios y de cocheros. Por su parte, las mujeres trabajaban como costureras, cigarreras, alpargateras, cocineras, lavanderas y mucamas. Es decir, el trabajo femenino abarcaba labores relacio-

en Tucumán (1895-1910)", en Entrepasados. Revista de Historia n. ${ }^{\circ} 35$, Buenos Aires, Universidad de Buenos Aires, 2009, y "El mutualismo y la compleja relación con el gremialismo (Tucumán, 1877-1914)", en María Celia Bravo y Sandra Fernández, Formando el espacio público. Asociacionismos y política. Siglos XIX y XX, Tucumán, Universidad Nacional de Tucumán (EDUNT), 2014, pp.57-77; Vanesa Teitelbaum, "El mutualismo en el mundo del trabajo (Tucumán, Argentina, 18771914)", Varia Historia vol.27, n. ${ }^{\circ}$ 46, Belo Horizonte, Universidades Federal de Minas Gerais, 2011, pp.665-688; "Contra la tiranía del mostrador. La campaña de la prensa y los trabajadores por el descanso dominical en Tucumán del entre-siglo", en Anuario de Estudios Americanos vol.68, n. ${ }^{\circ} 1$, Sevilla, EEHA, 2011, pp.223-252, "El Centro Cosmopolita de Trabajadores: un espacio de referencia del movimiento obrero en el norte argentino en los umbrales del siglo XX", en Estudios Sociales año XXI, n. ${ }^{\circ}$ 40, Santa Fe, Universidad Nacional del Litorial, 2011, pp.145-174; "Los centros obreros como ámbitos de cultura, protesta y política (Tucumán, 1895-1910)", en AA. VV., La clase obrera y el Centenario-1910- trabajos de investigación, Central de Trabajadores de la Argentina Ediciones, 2011, pp.71-112 y "Protección, cultura y sociabilidad: El Centro de Trabajadores de Socorros Mutuos de Monteros, (Tucumán, Argentina, 1890-1913)", en Encuentros Latinoamericanos n. ${ }^{\circ}{ }_{14}$, Montevideo, Universidad de la República, 2012.

15 Más información en M.C. Bravo y V. Teitelbaum, "Socialistas y católicos”, pp.67-87. 
nadas con el servicio doméstico, el trabajo a domicilio y la ocupación en las fábricas. ${ }^{16}$

Aunque atravesados por distintas situaciones laborales, el grueso de los trabajadores estaba expuesto a deficiencias y obstáculos en materia de higiene y de salud pública y sufría la dureza de los regímenes laborales signados por extensas jornadas de trabajo, accidentes de trabajo y salarios insuficientes, en un contexto caracterizado además por la falta de leyes sociales y laborales y la prácticamente ausencia del Estado en materia de políticas sociales y del trabajo. ${ }^{17}$

En ese marco podemos situar la emergencia y desarrollo del movimiento asociativo. De forma semejante a lo observado para otros escenarios locales, regionales y nacionales en América Latina, era la misma sociedad la que buscaba atender y resolver diversas problemáticas sociales y de trabajo a través de la constitución de asociaciones de naturaleza diversa, pero principalmente mediante la formación de sociedades de ayuda mutua. Otro tipo de asociación que cobró especial importancia en el mundo del trabajo fueron las sociedades de resistencia y gremios dirigidos especialmente a conseguir mejores condiciones de trabajo a través de estrategias de protestas que incluían petitorios, manifestaciones y huelgas. Y dentro de este universo asociativo adquirieron especial protagonismo los centros de trabajadores formados hacia finales de la década de 1890 al influjo de las corrientes de izquierda en el mundo del trabajo, como el anarquismo y el socialismo.

16 M.C. Bravo y V. Teitelbaum, "Socialistas y católicos", pp.67-87.

17 Juan Suriano, "El largo camino hacia la ciudadanía social", en Susana Torrado (comp.), Población y bienestar en la Argentina del primero al segundo Centenario. Una historia social del siglo $X X$, tomo I, Buenos Aires, Serie Estudios del Bicentenrio, Edhasa, 2007, pp.67-95; María Estela Fernández, "Las políticas de salud: el caso de los hospitales en Tucumán a fines del siglo XIX", $\mathrm{X}^{\circ}$ Jornadas Interescuelas/Departamentos de Historia, Rosario, 20 al 23 de septiembre, 2005; M. C. Bravo y V. Teitelbaum, "Socialistas y católicos”, pp.67-87. 


\section{1.- Veladas, conferencias y bailes en los gremios, mutuales y centros de trabajadores}

Una práctica frecuente en el mundo asociativo del novecientos fueron las veladas literario-musicales que organizaban los centros obreros, las mutuales y los gremios con el fin de recaudar fondos para su caja social, conmemorar eventos fundamentales de la vida de la institución, recordar efemérides patrias o evocar sucesos sobresalientes del calendario obrero. En una sociedad que asignaba un valor fundamental a la difusión de la propaganda, la educación y la cultura mediante la lectura en voz alta y las conferencias, los integrantes y los dirigentes asociativos pusieron en marcha numerosas fiestas compuestas por discursos y disertaciones a cargo de dirigentes obreros y líderes del mundo asociativo. Además, las fiestas incluían piezas teatrales, poesías y números de entretenimiento como rifas y bailes.

En ese contexto, podemos interpretar las actividades organizadas por el Centro Cosmopolita de Trabajadores, un ámbito fundamental de la vida asociativa en el mundo del trabajo, creado en 1897 e integrado principalmente por trabajadores de oficio. En su interior convivían liberales, anarquistas y socialistas, aunque es factible proponer que estos últimos dominaron las actividades del centro. A lo largo del periodo en que funcionó, comprendido entre 1897 -cuando se creó- y 1905 -fecha en la cual dejó de existir- sirvió como el espacio aglutinador de las principales prácticas de sociabilidad, cultura, protesta y política de los trabajadores de la ciudad de San Miguel de Tucumán. En esa dirección, preparó abundantes veladas y festivales que combinaban los fines de propaganda obrera, fomento a la educación y la cultura con el interés por ofrecer una alternativa para el ocio y el aprovechamiento del tiempo libre.

Dentro del repertorio de estas prácticas se destacaron las conferencias que abordaron un amplio y heterogéneo conjunto de temas relacionados con la cuestión social, el valor de la ciencia, la organización obrera, la democracia y el socialismo. En ocasiones, estas charlas versaron sobre problemas específicos del mundo del trabajo tucumano como la explotación de los trabajadores en los ingenios azucareros. Por lo general, tales disertaciones se realizaban en el contexto de las fiestas obreras que incluían, también, obras de teatro, poesías, himnos revolucionarios y concluían con un baile que atraía a los trabajadores y sus familias. Una muestra en ese sentido se reveló en la velada literaria que en 1901 encabezó el Centro Cosmo- 
polita de Trabajadores. Allí, niños recitaron poesías, se pronunciaron discursos sobre la doctrina socialista y acerca de la vida poco humana que enfrentaban los peones en algunos ingenios azucareros y finalmente la fiesta concluyó con un baile. ${ }^{18} \mathrm{~A}$ los pocos días el Centro Cosmopolita de Trabajadores desarrolló otra velada destinada a celebrar el fin de siglo con discursos, poesías alusivas, como "Mi Bandera" y, por último, un baile. ${ }^{19}$

A su vez, el Centro Cosmopolita de Trabajadores sirvió como un espacio de reunión de sociedades mutuales y gremiales que utilizaron su local para desarrollar sus asambleas y veladas culturales y sociales. Ejemplo de lo anterior fue el festival que en 1903 encabezó la asociación de socorro mutuo que reunía al gremio de los tipógrafos, la sociedad Unión Tipográfica, con conferencias sobre propaganda obrera y temas de actualidad a cargo de renombrados dirigentes locales, como el tipógrafo y masón Daniel R. Villagrán. El evento, como era usual, terminó con un baile. ${ }^{20}$

Es sabido el destacado papel desempeñado por el oficio tipográfico en las prácticas de los trabajadores de la época, característica que trascendía el escenario local, regional y nacional. En ese sentido, las actividades motorizadas por los tipógrafos adquirieron notoria influencia y se revelaron en un abanico de expresiones orientadas a estimular la educación, la sociabilidad y la cultura de sus miembros a través de proyectos para crear bibliotecas y fundar periódicos. ${ }^{21} \mathrm{Al}$ respecto, podemos mencionar la edición de El Eco del Obrero, órgano de expresión de la asociación tipográfica en Tucumán. ${ }^{22}$

Heredero de la tradición del Centro Cosmopolita, en 1905 comenzó a funcionar el Centro Socialista que también actuó como un ámbito de reunión de gremios y mutuales de trabajadores y fue el lugar elegido para sus actividades asociativas. A modo ilustrativo, podemos mencionar las prácticas de sociabilidad que se llevaron a cabo en junio y octubre de ese año, como la conferencia obrera de la aso-

18 El Nacional, 3 de enero de 1901.

$19 \quad$ La Vanguardia, 12 de enero de 1901.

20 El Orden, 3 de septiembre de 1903.

21 Por ejemplo, AHT, SA, año 1894, vol.206.

22 “Al respecto", en El Orden, 4 de marzo de 1903. 
ciación gremial de herreros y el baile de la sociedad gremial de obreros sastres que se prolongó hasta las primeras horas del día siguiente. ${ }^{23}$

De forma semejante al Centro Cosmopolita de Trabajadores, las actividades motorizadas por el Centro Socialista reunían varios propósitos. Principalmente, buscaban atraer, concientizar y educar a los trabajadores en las consignas del socialismo y aspiraban a conformar identidades obreras entre los asociados. De acuerdo con esos fines, las celebraciones recurrían a los tópicos característicos de la cultura obrera, como himnos revolucionarios y dramas sociales. En particular las veladas incluían además de discursos a cargo de militantes y dirigentes socialistas, la participación de coros y orquestas de trabajadores que entonaban canciones e himnos revolucionarios, como "Hijos del Pueblo" y "La Internacional", la representación de piezas teatrales como "Madre creyente, hijo socialista" y la declamación de poesías sociales y contestatarias como "De horas tristes" y "La huelga".

En esa dirección son abundantes las celebraciones que confeccionaron programas con números característicos de la cultura obrera. Las palabras de los líderes obreros, los números artísticos y culturales y los entretenimientos como rifas y bailes representaban atractivos para el trabajador y su familia que podían compartir prácticas de sociabilidad, cultura y recreo en un ámbito propio. ${ }^{24} \mathrm{Al}$ respecto, podemos mencionar la velada literario-musical motorizada por el Centro Socialista al despuntar el año 1906:

Programa

Primera parte

$1^{0}$ "La internacional" por la orquesta

$2^{\circ}$ Discurso de apertura por el compañero Rodolfo Terchini Walker

$3^{\circ}$ La Internacional, declamada por la niña Ema Petersen

$4^{\circ}$ Declamación titulada "La Canalla” por el niño Vázquez

23 El Orden, 26 de junio de 1905 y 30 de octubre de 1905.

24 Joan Casanovas, al estudiar las actividades organizadas por la sociedad de instrucción y recreo denominada Recreo de Obreros" que funcionó en la ciudad de La Habana, en Cuba, entre 1879 y 1884, menciona a las veladas familiares de los domingos, en las cuales los trabajadores veían obras de teatro, escuchaban conferencias o lecturas de poesías y conciertos de música. Mayoritariamente, dichas fiestas concluían con un baile que fue seguramente la actividad motorizada por la asociación el Recreo que "más gustaba a los artesanos y sus familias". Joan Casanovas, "El artesanado habanero y los orígenes del Círculo de Trabajadores”, en Historia Social n. ${ }^{\circ} 31$, Valencia, Centro de la UNED Alzira-Valencia, Instituto de Historia Social, Fundación Historia Social, 1998, p.114. 
$5^{\circ}$ Discurso por el compañero Luis Amaro

$6^{\circ}$ Poesía recitada por la niña Ortensia Ferrazano

$7^{0}$ "Himno de los Trabajadores", por Felipe Turati, cantado por el coro.

Segunda Parte

$1^{\circ}$ Himno al 1 de Mayo por la orquesta

$2^{\circ}$ Discurso de la compañera Alcira Gómez

$3^{\text {o }}$ Poesía "El Nuevo Evangelio" recitada por el niño Fernández

$4^{\circ}$ Poesía "La Rebelión" recitada por la niña Peralta

$5^{\circ}$ Discurso por el compañero Dr. Mario Bravo

$6^{\circ}$ Himno "Los Hijos del Pueblo", cantado por el coro

$7^{\circ}$ Discurso de clausura por el compañero Argañaráz

$8^{\circ}$ Sorteo de la rifa

$9^{\text {o }}$ Baile Familiar. ${ }^{25}$

De características similares al Centro Cosmopolita de Trabajadores, el Centro Socialista mostró una afiliación aún más explícita al partido Socialista. En esa dirección, y al igual que los gremios que se reconocían como parte del socialismo, sus eventos mostraron una clara intención política destinada a atraer militantes y engrosar las filas del partido. Bajo esos parámetros podemos situar la fiesta proyectada por la Sociedad de Resistencia de Albañiles y Anexos para celebrar su cuarto aniversario en el local del Centro Socialista cuyo programa era el siguiente:

Programa

Primera Parte

$1^{\circ}$. Música de la orquesta.

$2^{\mathrm{O}}$ Discurso de apertura por los compañeros Antonio Baralo y José Quagliata.

$3^{\mathrm{o}}$ Declamación por la niña Ema Palecer, La Internacional.

$4^{\circ}$ Discurso por el compañero Domingo J. Romero.

$5^{\mathrm{o}}$ Hijos del Pueblo cantado por un coro de niños y compañeros del Centro Socialista.

Segunda Parte

$1^{\circ}$ Música por la orquesta

$2^{\mathrm{O}}$ Discurso por la compañera Silvia Larreras.

$3^{\circ}$ Declamación por el niño Fernández, el Nuevo Evangelio.

$4^{\circ}$ Discurso del compañero Domingo J. Romero.

$5^{\text {o }}$ Himno de los trabajadores cantado por el coro. ${ }^{26}$

25 El Orden, 23 de enero de 1906.

26 El Orden, 22 de junio de 1906. 
Hacia finales de la primera década del siglo xx se observó un cambio en los espacios elegidos para las veladas. El crecimiento de los centros obreros, de las asociaciones gremiales y de las sociedades de socorro mutuo obligó a buscar nuevos locales para la celebración de las fiestas y, en ese sentido, las sedes de las mutuales de tipo étnicas como la Sociedad Italiana se vislumbraron como los lugares apropiados. Un ejemplo de lo anterior fue la velada organizada en 1908 por la sociedad Unión Tipográfica de Socorros Mutuos a beneficio de su caja social. Según noticias de la prensa, la fiesta fue un verdadero éxito y demostró la cultura que caracterizaba a esa asociación, así como el incremento en el número de sus asociados. ${ }^{27}$ También la sociedad gremial de carpinteros recurrió al local de la Sociedad Italiana para la velada y el baile que en 1910 encabezó en beneficio de su caja social. Entre los números previstos se encontraba la actuación del cuadro "Luz y Arte" que representaría el drama iUna limosna por Dios! y conferencias sobre temas de sociología e instrucción. ${ }^{28}$ Por su parte, el Centro Socialista preparaba en los salones de la Sociedad Italiana un festival obrero para la noche del 22 de marzo de 1913 cuyo fin era reunir fondos para la caja social de la institución. Algunos de los espectáculos contemplados fueron la participación de un cuadro filo-dramático de aficionados, compuesto por miembros del centro, que representaría las obras "Hambre" de Dante Silva y i"Que calor con tanto viento...!" de José Maturana y la actuación de un coro de señoritas, acompañado por una orquesta, que cantaría "La Internacional" y "Los hijos del pueblo". ${ }^{29}$ Finalmente un numeroso público disfrutó de la velada que culminó con un baile y que tras algunas variaciones incluyó discursos, la obra de teatro "Los Nuevos parias", el monólogo "Uno de Tantos" e himnos revolucionarios como La Marsellesa, Hijos del Pueblo y La Internacional, además de una rifa y un baile familiar.

Programa

Primera Parte

$1^{\circ}$ Sinfonía por la orquesta

$2^{\circ}$ Apertura del acto por el Secretario General del Centro

$3^{\circ}$ La Marsellesa cantada por el coro

$4^{\circ}$ Vals por la orquesta

27 El Orden, 11 de noviembre de 1908, 5 y 7 de diciembre de 1908.

28 El Orden, 20 de octubre de 1910.

$29 \quad$ La Gaceta, 13 de febrero de 1913. 
$5^{\circ}$ Subirá a escena el aplaudido drama en un acto titulado Los Nuevos Parias cuyo elenco artístico corresponde al poderoso cuadro de aficionados Luz y Arte que tan desinteresadamente presta su concurso.

Segunda Parte

$1^{\circ}$ La Sinfonía por la orquesta

$2^{\circ}$ Discurso por la Srta. Alcira Gómez.

$3^{\mathrm{O}}$ Los Hijos del Pueblo cantado por el coro.

$4^{\circ}$ Vals por la orquesta

$5^{\mathrm{o}}$ Monólogo recitado por el compañero Cesareo Fanjul titulado Uno de

Tantos

$6^{\circ}$ Sorteo de la rifa

Gran baile familiar. ${ }^{30}$

El programa --representativo del conjunto de veladas socialistas de los trabajadores en Tucumán durante la época estudiada-- reprodujo un patrón de sociabilidad y cultura que recuperaba los tópicos característicos de la cultura obrera a través de himnos revolucionarios, obras de teatro y poesías sociales y contestatarias. De esta manera, las fiestas podrían contribuir al aprendizaje y difusión de las consignas del socialismo y favorecer la creación de identidades y militancias obreras entre los integrantes de los centros obreros como el Centro Cosmopolita y, más tarde, del Centro Socialista.

Por otra parte, los fines principales de las mutuales, de los gremios y de las sociedades de resistencia no impedían que dichas asociaciones llevaran adelante veladas, conferencias y bailes que permitían satisfacer otras aspiraciones de las clases trabajadoras relacionadas con el recreo, la sociabilidad, el acceso a la educación y el fomento a la cultura. Además, en muchos casos las fiestas se organizaban para recaudar fondos para la caja social de la sociedades y, por esa vía, concretar sus objetivos primordiales referidos al socorro, en el caso de una mutual, o al mejoramiento de las condiciones de vida y de trabajo, en el caso de los gremios. En suma, las fronteras entre las sociedades eran porosas y muchas veces las asociaciones, combinaban sus propósitos genéricos con otras funciones, como aquellas relacionadas con la educación, la sociabilidad y la cultura.

En esa tónica, podemos inscribir también las actuaciones de una renombrada mutual de trabajadores del interior de la provincia: el Centro de Trabajadores de Socorros Mutuos de Monteros, ámbito fundado -como ya se dijo- en 1899 y que

30 La Gaceta, 20 de marzo de 1913. 
funcionó, por lo menos, hasta la década de 1970. Integrado mayoritariamente por artesanos organizó actividades de naturaleza social, cultural y de recreo, como fiestas, funciones de teatro, bailes y rifas. Por lo general, estos eventos se efectuaron para conseguir recursos económicos destinados a costear los gastos que implicaban la edificación de su salón social y la construcción de un panteón propio en el cementerio.

Paralelamente, estas prácticas de sociabilidad, cultura y recreo permitían a los trabajadores disfrutar su tiempo libre a través del encuentro con los otros asociados en momentos de esparcimiento, diversión y aprendizaje. A estos fines, contribuían especialmente espacios como el juego de billar y la cantina que durante algún tiempo y administrada por particulares funcionó en el local del Centro de Trabajadores. ${ }^{31}$

En suma, las actividades de sociabilidad, cultura y recreo, como las fiestas, los bailes, las funciones de teatro, la asistencia a la cantina o la participación en el juego conformaban atracciones para los trabajadores, quienes de esa forma podían encontrar en la mutual no solo un espacio de protección y ayuda mutua sino también un ámbito para compartir con otros socios eventos de entretenimiento, desarrollo cultura y recreo. Percibidas como expresiones más libres y menos reglamentadas, en comparación con las sesiones de la comisión directiva o las asambleas, es decir, las reuniones formales de la asociación, las prácticas vinculadas con la sociabilidad, la cultura y recreo actuaron como facetas distintas pero complementarias de las tareas de socorro mutuo.

Otra evidencia de la combinación de funciones en la vida asociativa se reflejó en el artículo publicado en 1907 por El Tipógrafo, fuente que elogiaba mediante un lenguaje sentido y comprometido el papel asumido por el sindicato de Mozos. Según este periódico gremial, la asociación de mozos se había hecho cargo del velorio y del sepelio de uno de sus miembros, el obrero Juan Vera, quien trabajaba en el hotel Frascati de la ciudad y había fallecido a causa de una rápida enfermedad. ${ }^{32} \mathrm{Si}$ bien noticias como estas no fueron las más usuales, su localización permite sugerir que algunas sociedades gremiales efectuaron prácticas de ayuda mutua, especialmente valoradas como la cobertura ante el fallecimiento. Dato que adquiere espe-

31 BPO. BF. Comisiones Directivas 1899-1908.

32 El Tipógrafo, 23 de junio de 1907. 
cial interés si consideramos la importancia otorgada por los trabajadores al ritual de un entierro digno, tal como propone Eduard Thompson. ${ }^{33}$

\section{2.- La construcción de la fiesta de los trabajadores}

En Argentina, desde 1890 los socialistas convocaron a los trabajadores a dedicar un día a la lucha obrera y a conmemorar la explotación y la injusticia que sufría la clase trabajadora. Ese día fue el $1^{\circ}$ de mayo, efeméride central del calendario obrero que reunía los propósitos de recreación, cultura y propaganda en celebraciones organizadas todos los años por las sociedades de trabajadores. ${ }^{34}$ Desde 1896-1897 contamos con evidencias fehacientes de la celebración del Primero de Mayo entre los trabajadores tucumanos. Y fue al despuntar el novecientos, cuando esta conmemoración adquirió mayor impulso, tal como se reflejó, por ejemplo, en la reunión que en 1901 realizaron artesanos y obreros en el Centro Cosmopolita de Trabajadores para preparar el programa de festejos que incluyó conferencias dictadas por dirigentes obreros como el tipógrafo Daniel López y renombrados liberales preocupados por la cuestión social, como Paulino Rodríguez Marquina. Otro discurso fundamental impartido ese $1^{\circ}$ de mayo por el del reconocido líder del socialismo Nicolás Repetto, quien visitó la provincia en representación del Partido Socialista Argentino y habló en la reunión de los trabajadores que tuvo lugar en la plaza Independencia, actualmente el principal paseo público de la ciudad. Ese año la celebración contó también con un banquete en el Hotel Frascati, ${ }^{35}$ práctica característica de la sociabilidad burguesa que más adelante fue dejada de lado en las conmemoraciones de los trabajadores. Paralelamente, la actuación de dirigentes reformistas y liberales también se debilitó en el repertorio de expresiones obreras. ${ }^{36}$

33 Edward P. Thompson, La formación de la clase obrera en Inglaterra, tomo I, Barcelona, Crítica, 1989, pp.464-476.

$34 \quad \mathrm{El} 1^{\circ}$ de mayo recordaba el asesinato de los presos en Chicago en 1887 y fue definido como un ritual esencial para el socialismo, movimiento que inauguró esta tradición, y como "el único aniversario asociado exclusivamente con el proletariado", según la percepción del anarquismo, tal como sostiene J. Suriano, Anarquistas, p.318.

35 El Orden, 12 y 30 de abril de 1901, 1, 2 y 6 de mayo de 1901.

36 M. C. Bravo y V. Teitelbaum, "Socialistas y católicos, p.77.

Dossier: Artesanos: formas de trabajo, sociabilidades, movilidad social y cultura política en Hispanoamérica, siglos XVI-XX 
En contraste, se conservó y construyó un itinerario de conmemoración que abarcó dos grandes momentos. Por un lado, la manifestación de los trabajadores en las calles y plazas de la ciudad y, por el otro, la velada que se efectuaba en la sede de las asociaciones obreras. Por lo general, las reuniones públicas partían de un punto nodal -la sede del centro obrero, una plaza o una esquina muy céntrica- desde la cual los trabajadores comenzaban a marchar organizados en columnas y recorrían los lugares emblemáticos de la vida urbana, concluyendo en un acto central que invariablemente tenía lugar en algunas de las principales plazas de la ciudad. ${ }^{37}$ Acompañados de los símbolos fundamentales del movimiento obrero, como la bandera roja, y secundados por bandas de música que ejecutaban himnos revolucionarios, los trabajadores desfilaban por la ciudad, mostrando su fuerza y organización. ${ }^{38}$ Por otra parte, en la tarde-noche, se efectuaba generalmente la fiesta en el local de los centros obreros. En tales veladas sobresalían los discursos que además de explicar los significados del Primero de Mayo instaban a los trabajadores a participar en la vida política y a apoyar al socialismo. Tal fue el caso de la celebración de 1902,

una velada a la que asistió tanta concurrencia -en su mayoría obreros- que por primera vez se sintió la necesidad de un local más grande, tanto que se tuvo que salir al patio y allí se dieron las conferencias. El compañero Antonio Masucci abrió el acto leyendo un hermoso discurso que por repetidas veces fue aclamado por la enorme concurrencia. El compañero Manuel R. Bracamonte explicó el significado del 1 de mayo. Hizo historia de esta fecha, condenó el régimen actual de cosas, criticó la política criolla, puso de manifestó la ignorancia del obrero en nuestros tiempos, a pesar de nuestra activa propaganda, y abogó

37 "Los recorridos de las manifestaciones constituían activas demarcaciones territoriales en el espacio urbano", señala Mirta Zaida Lobato en su análisis sobre las movilizaciones que acompañaban los rituales del $1^{\circ}$ de mayo en el Río de la Plata Mirta Zaida Lobato, La prensa obrera, Buenos Aires, Edhasa, Temas de la Argentina, 2009, p.175.

38 Bandas de música que ejecutaban el Himno a los Trabajadores, La Marsellesa y otras canciones obreras, manifestantes portando banderas rojas y accesorios de ese color formaban parte esencial de las marchas organizadas por los socialistas los $1^{\circ}$ de mayo, tal como lo señalaba en su estudio, Aníbal Viguera, "El primero de mayo en Buenos Aires, 1890-1950: evolución y usos de una tradición", en Boletín del Instituto de Historia Argentina y Americana "Dr. E. Ravignani", Tercera Serie, n. ${ }^{\circ}$ 3, Buenos Aires, Universidad de Buenos Aires, 1991, pp.57-60, Sobre las manifestaciones obreras en los espacios públicos resultó sugerente, además, el análisis de Mirta Lobato y Silvana Palermo, "Del trabajo a las calles: dignidad, respeto y derechos para los y las trabajadoras", en Mirta Lobato (ed.), Buenos Aires. Manifestaciones, fiestas y rituales en el siglo $\mathrm{XX}$, Buenos Aires, Biblos, 2011, pp.45-74. 
por su organización en partido de clase para luchar en el terreno político y económico por el bienestar de todos [...] En seguida se declaró la tribuna libre y los compañeros Montovani y Márquez expusieron con gran acierto las teorías socialistas. En resumen: la fiesta del 1 de mayo estuvo como ningún año; y puede decirse que los trabajadores del centro cosmopolita han entrado a una nueva vida de lucha. ${ }^{39}$

Un momento central de las manifestaciones en calles y plazas ocurría también cuando los líderes socialistas se dirigían a los trabajadores con palabras alusivas a la fecha y a la gesta obrera. Gradualmente, fue notoria la influencia del socialismo en estas conmemoraciones, lo cual se evidenció en las reiteradas visitas de propagandistas obreros provenientes de Buenos Aires y del Litoral, que intervinieron en los festejos del $1^{\circ}$ de mayo en Tucumán. ${ }^{40}$ En esa dirección, podemos situar las visitas de Adrián Patroni, destacado dirigente obrero del socialismo que desempeñó un papel clave en el asociacionismo laboral tucumano al encabezar en 1904 la huelga de peones y jornaleros azucareros que se desplegó en la mayoría de los ingenios de Cruz Alta. Dos años antes de este gran conflicto obrero, en mayo de 1902, Patroni dictó una conferencia en la sede del Centro Cosmopolita de Trabajadores, sobre el socialismo y la organización de los obreros y otra titulada "Democracia cristiana y socialismo" en el local de la Sociedad Española, una de las mutuales más antiguas de Tucumán. ${ }^{41}$

Luego de la efervescencia asociativa, cultural y de protesta que caracterizó al año 1904, en consonancia con el incremento y la visibilidad de la conflictividad obrera plasmado en un ciclo de protestas cuya máxima expresión fue la huelga de trabajadores azucareros, observamos algunas transformaciones significativas en las expresiones asociativas del mundo del trabajo. Una muy importante fue el crecimiento de la agremiación de los trabajadores, tanto en las áreas rurales como en las urbanas. Para entonces, el grueso de los oficios contaba con una sociedad gremial o de resistencia. Por otro lado, es factible detectar una mayor participación de las mujeres en las prácticas asociativas. Ejemplo de lo anterior fue la velada literariomusical para conmemorar el $1^{\circ}$ de mayo de 1905 que tuvo lugar en la sede del Cen-

$39 \quad$ La Vanguardia, 10 de mayo de 1902.

$40 \quad$ La Vanguardia, 10 de mayo de 1902.

41 La Vanguardia, 10 de mayo de 1902. Véase además El Orden, 6 y 7 de mayo de 1902. 
tro Socialista. Allí, tomó la palabra una militante, Rosa Rodríguez, quien se refirió a la efeméride y al socialismo.

(...) $\mathrm{El} 1^{0}$ de mayo nos invita a todos sin distinción de sexos a entrar en una nueva vida, que el socialismo enseña que es de trabajo y paz, de luz y de verdad y de regeneración social.

(...) Cábeme la satisfacción en este instante en que los corazones proletarios laten al impulso del bello ideal socialista, de hacer entrega de la bandera a este centro, confeccionada por mis compañeras entusiastas, siendo mis votos por que la hagáis flamear siempre inmaculada, hasta que logréis implantarla victoriosa en la alta cumbre desde donde la nueva humanidad contemple satisfecha la obra redentora del socialismo. iViva el $1^{\circ}$ de mayo! ${ }^{42}$

Transcribí parte del discurso de Rosa porque considero relevante su testimonio de Rosa, ya que no contamos con fuentes que proporcionen la voz de las trabajadoras para el espacio y el periodo analizado en esta investigación. Asimismo, estas palabras, publicadas en La Estrella del Norte. Semanario liberal y defensor de la clase trabajadora, fuente sobre la cual hasta ahora no teníamos noticia, proporciona mayor información en torno a las expresiones socialistas locales al revelar el uso del vocabulario e ideario socialista por parte de mujeres que, como Rosa, se involucraron activamente en las actividades asociativas.

Otro valioso documento sobre las manifestaciones de los trabajadores fue sin duda Germinal, el número editado por la Federación Obrera Local Tucumana, creada en 1906 e integrada por asociaciones de trabajadores de la ciudad de San Miguel de Tucumán. ${ }^{43}$ Esta publicación que constaba de 4 páginas constituye sin duda uno de los testimonios más valiosos sobre la conmemoración del $1^{\circ}$ de Mayo en Tucumán, ya que contiene poesías, discursos y mensajes alusivos a la fecha y a otros temas de organización obrera. A su vez es una de las muy escasas fuentes sobre el anarquismo en la provincia en la primera década del siglo XX. Las miradas, juicios y análisis de militantes anarquistas en torno la principal conmemoración obrera se desprenden de los artículos publicados en Germinal. En líneas generales podemos afirmar que el anarquismo definía al Primero de Mayo como un día de

42 La Estrella del Norte, 14 de mayo de 1905.

$43 \mathrm{Al}$ respecto, Santiago, Bilbao, "Anarquismo en el noroeste a principio del siglo Xx: Germinal, publicación tucumana”, en Estudios del Trabajo n. ${ }^{0} 28$, Buenos Aires, ASET, 2004, pp.143-151.

Dossier: Artesanos: formas de trabajo, sociabilidades, movilidad social y cultura política en Hispanoamérica, siglos XVI-XX 
protesta y de lucha, totalmente opuesta al significado festivo que, según argumentaban los miembros de la corriente libertaria, buscaban otorgarle a esta fecha los socialistas. $\mathrm{Al}$ respecto, podemos mencionar los comentarios firmados con el seudónimo PVP, probablemente provenientes de Tomás Delgado, ${ }^{44}$ uno de los principales dirigentes del anarquismo en Tucumán, quien hacia 1907 se desempeñaba como uno de los principales activistas de la Federación Obrera Local. Según esta nota, "el primero de Mayo no es un día de fiesta para la clase desposeída, aunque así lo afirmen los socialistas, los que ofician de rebañizadores. El primero de mayo es día de recordaciones y de protestas". De acuerdo con estas consideraciones, el anarquismo desestimaba participar en "las plazas públicas en procesión apacible y decorativa, quede ello para los socialistas, los arlequines y los amantes del orden estatal". Por el contrario, ellos proponían salir "a la calle no para cantar nuestros dolores en estrofas sentimentales sino para hacer algo más que todo eso, para exigir la parte que nos corresponde en este banquete social al que aportamos todo el caudal de nuestras energías y todo lo que se expone en la mesa". En esa dirección, concluía el artículo asegurando el verdadero significado del Primero de Mayo era el de un "día de recordación y de afianzamiento de fe". 45

Sin embargo, en la época estudiada los socialistas no se pronunciaron de forma tan explícita y contundente por el sentido festivo del $1^{\circ}$ de Mayo. En contraste, es factible proponer que esta noción se construyó gradualmente. En esa tónica, un testimonio revelador de las interpretaciones que podían encontrar puntos de contacto entre el anarquismo y el socialismo en torno al Primero de Mayo fue otra noticia difundida por Germinal. Dicha nota fue elaborada por un dirigente socialista como Horacio Stabile, quien a comienzos del novecientos había formado parte de la Comisión Directiva del Centro Cosmopolita de Trabajadores y poco tiempo después se desempeñó como secretario de actas en la sociedad gremial Obreros Sastres. ${ }^{46}$ Titulado sugestivamente "Mi voz al esclavo", este escrito aseguraba que

44 Sobre Tomas Delgado y su participación en Germinal, ver: S. Bilbao, "Anarquismo en el noroeste”, pp.143-151. Además, Delgado participó encabezando la velada y la conferencia libertaria dedicada a las clases trabajadoras organizada por esta Federación Obrera Local en septiembre de 1907 en el Teatro Belgrano. Inaugurado con las palabras del líder de la Federación, Tomás Delgado, el acto incluyó también cantos revolucionarios, declamaciones poéticas y las palabras de dirigentes provinciales y delegados de la FORA. El Orden, 27 de septiembre de 1907.

45 "El $1^{\circ}$ de mayo", en Germinal, 1 de mayo de 1908.

${ }^{46}$ El Orden, 29 de agosto de 1901, 27 de agosto de 1904, 8 de junio de 1905, 11 de noviembre de 1905, 26 de julio de 1906 y 1 de marzo de 1909.

Dossier: Artesanos: formas de trabajo, sociabilidades, movilidad social y cultura política en Hispanoamérica, siglos XVI-XX 
"el primero de mayo no es una fiesta para los asalariados sino un día de protesta contra nuestros explotadores, un día de protesta contra todos los poderes constituidos como ser el estado pontificio, ese estado que representa la religión católica, apostólica, la cual hace un siglo que domina el mundo." Posteriormente, Stabile apuntaba que los gobiernos y el capital eran los otros dos poderes que oprimían al proletariado y concluía afirmando que el $1^{\circ}$ de mayo simbolizaba "la protesta unánime de todos los hombres de trabajo contra esos poderes sin fundamento, porque no tienen razón de ser, basado en la forma de esclavitud del presente régimen social". ${ }^{4}$

Durante la segunda década del siglo xx el crecimiento del socialismo en la capital del país alentó a los dirigentes locales a incrementar sus labores de propaganda. En ese contexto, podemos citar los esfuerzos realizados por el Centro Socialista local para difundir su programa partidario y atraer militantes a lo largo y ancho de la provincia. Ejemplo de lo anterior fue la gira de propaganda obrera encomendada a dos miembros del centro obrero para recorrer el interior de Tucumán: las villas de Lules, Famaillá, Monteros, Concepción, Medinas, Aguilares, Villa Alberdi, Graneros, Lamadrid, Monteagudo, Simoca, Bella Vista, Tafí Viejo y Cruz Alta. 48

Paralelamente, los anarquistas adquirieron mayor presencia en la provincia, tal como se reflejó en la actuación de algunos líderes locales que cobraron mayor visibilidad y en la militancia que se observó en algunas ciudades del interior, como Tafi Viejo, espacio estrechamente asociado al trabajo de los Talleres Ferroviarios que inaugurados en 1910, con motivo del Centenario de la Independencia, comenzaron a funcionar aproximadamente en el año 1912.

Fue entonces cuando las manifestaciones del $1^{\circ}$ de Mayo involucraron a un número mayor de participantes y reflejaron la creciente complejidad del movimiento obrero. Así, por ejemplo en 1913, los socialistas celebraron la efeméride con una numerosa manifestación que recorrió los espacios públicos de la ciudad y en la cual sobresalió la presencia de las mujeres trabajadoras que asumieron parte activa en

47 Germinal, 1908, 1 de mayo de 1908.

$48 \quad$ La Gaceta, 19 de diciembre de 1912. 
la fiesta del trabajo. Por su parte, los anarquistas realizaron una velada literaria en el local de la Sociedad Italiana a la cual asistió una gran concurrencia. ${ }^{49}$

$\mathrm{Al}$ año siguiente, en 1914, la conmemoración del $1^{\circ}$ de mayo incluyó la conferencia a cargo de renombrado líder socialista Gregorio R. Pinto y una función cinematográfica sobre temas socialistas. A su vez, y tal como estaba previsto, el acto central se realizó en la Plaza Independencia y contó con la participación del Dr. Mario Bravo, reelegido recientemente recomo diputado nacional y enviado a Tucumán como delegado del Comité Nacional del partido Socialista. Su papel en el socialismo nacional, sumado a su origen tucumano, hacían de Bravo una figura atractiva para el público local que en gran número se dio cita en la plaza para escuchar la conferencia político-social del "distinguido comprovinciano". ${ }^{50}$ En su discurso, el orador explicó lo que significaba el $1^{\circ}$ de mayo y la razón que tenían los trabajadores para celebrarlo: "es un día de afirmación y de protesta. Se revistan las filas del proletariado, se mira el camino andado y se contempla la obra de la emancipación, para luego, con mayor entusiasmo y bríos, seguir adelante". ${ }^{51}$

De esta forma, Bravo sintetizaba el pensamiento socialista en torno al $1^{\circ} \mathrm{de}$ mayo como una conmemoración que articulaba las dos nociones: de afirmación de la clase trabajadora y de protesta. En esa tónica y siguiendo a la bibliografía sobre el tema, es factible proponer que mientras el anarquismo definía al $1^{\circ}$ de mayo como una jornada luctuosa y de lucha obrera, el socialismo postulaba los dos sentidos, el festivo y el de protesta, en la medida que definía a la efeméride como una ocasión especialmente propicia para la manifestación pacífica de los trabajadores por sus reclamos. ${ }^{52}$ Aunque este tema trasciende ya los objetivos planteados en el trabajo, podemos afirmar que, gradualmente, la interpretación socialista del Primero de Mayo fue la que se impuso en las prácticas de los trabajadores. ${ }^{53}$

$49 \quad$ La Gaceta, 3 de enero de 1913.

50 El Orden, 27 de abril de 1914 y 1 de mayo de 1914.

51 La Gaceta, 2 de mayo de 1914.

52 A. Viguera, "El primero de mayo", p.6o; J. Suriano, Anarquistas, p.318; M. Lobato, La prensa obrera, p.175, y M. Lobato y S. Palermo, "Del trabajo a las calles", pp.45-74.

53 M. Lobato, La prensa obrera, p.175, y M. Lobato y S. Palermo, “Del trabajo a las calles”, pp.4574 . 
La magnitud y relevancia del mitin de 1914 quedaron registradas en una imagen poco nítida pero sumamente valiosa, ya que constituye la primera fotografía sobre el $1^{\circ}$ de mayo en Tucumán (imagen 1). Aunque no podemos dar una respuesta definitiva sobre las razones que llevaron a tomar esta fotografía y difundirla en el principal diario local de la época, El Orden, tiene sentido pensar que la misma podía ser indicativa del interés que manifestaba la opinión pública por la conmemoración del Primero de Mayo. Asimismo, ilumina acerca del propósito de los trabajadores por demostrar su fuerza y exhibir sus demandas ocupando espacios públicos claves como la plaza Independencia. ${ }^{54}$

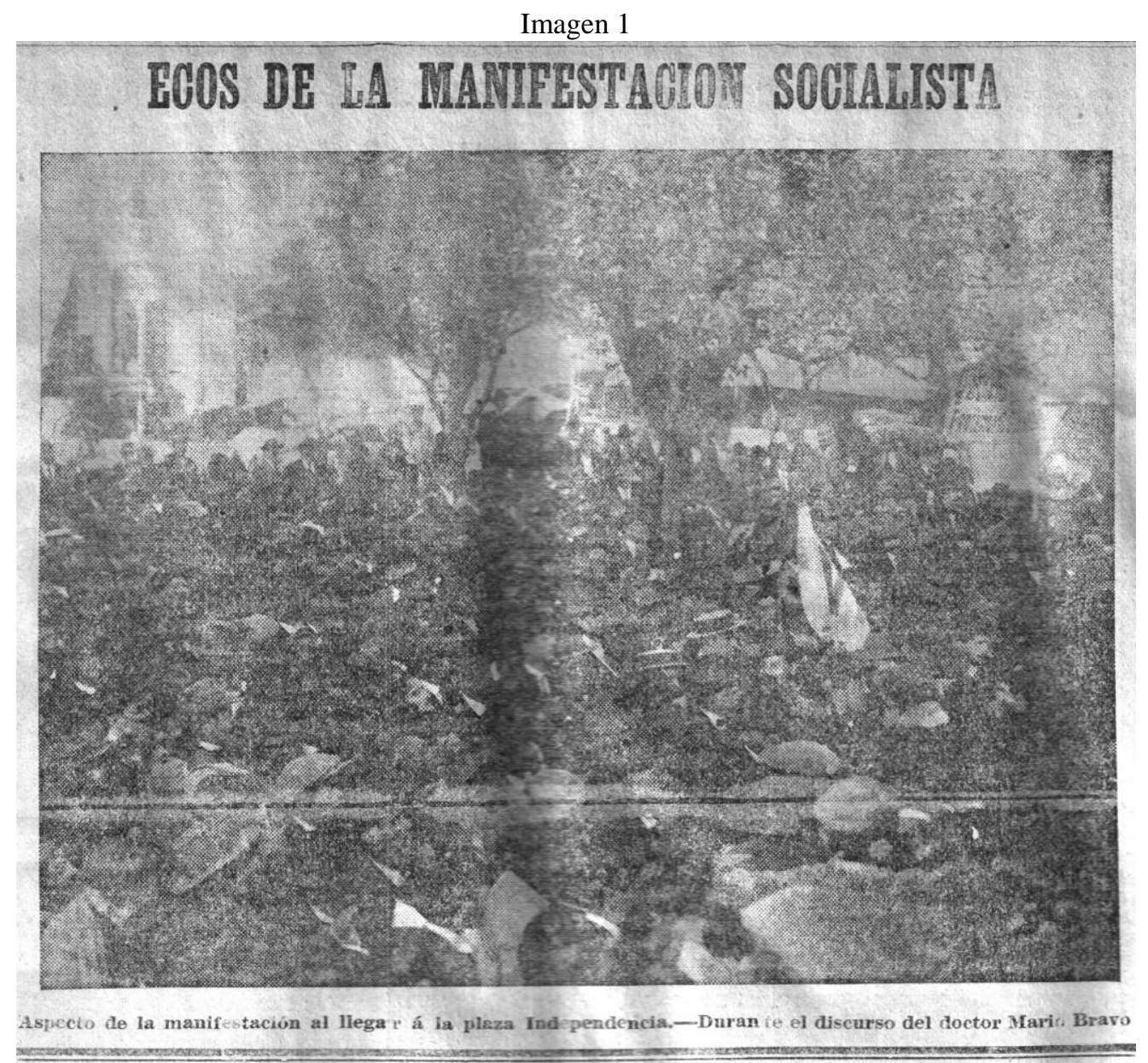

Fuente: El Orden, 2 de mayo de 1914

54 Isabel Bilhão, "Dia de festa, dia de luto ou feriado nacional? As diferentes concepções do Primero de Maio no Brasil ao longo dos anos 1929", em Hib, Revista de Historia Iberoamericana vol.6, n. ${ }^{\circ}$, Santiago de Chile, Universia, 2013, pp.29-52. 
Por su parte, la Federación Obrera Local, que agrupaba la corriente anarquista en la provincia, celebró el $1^{0}$ de mayo con una manifestación en las plazas Alberdi y en la plaza Humberto I y contó con oradores como Ángel F. Derisso, Luis E. Mones y Tomás Delgado. ${ }^{55}$ Estos dirigentes tuvieron también una activa participación en el interior de Tucumán, particularmente en la ciudad de Tafí Viejo, a través de las conferencias tituladas "Ineficacia en las luchas obreras", "Política y políticos" y "Acción económica y acción política” organizadas por la Federación Obrera Local Tucumana para desestimar la participación de los trabajadores en la política partidaria. Según la central obrera "a raíz de un reciente triunfo eleccionario en Buenos Aires un partido político pretende encauzar en esta provincia la lucha proletaria [que] fue, es y será siempre una cuestión económica”. ${ }^{56}$ Por esta vía, los anarquistas hacían referencia implícita al partido Socialista, sus principales rivales en la organización del movimiento obrero.

Asimismo, el anarquismo alcanzó mayor presencia en el mundo de los gremios al incluir por ejemplo a los oficiales peluqueros, quienes decidieron ingresar a la Sociedad Oficios Varios, adscripta a la Federación Obrera Local Tucumana, hasta tanto existiera un núcleo mayor de 30 oficiales, cifra que les permitiría formar parte de la Federación directamente. Para ello, resolvieron nombrar como delegados a dos compañeros. A su vez, acordaron lanzar un manifiesto invitando al gremio a abandonar el trabajo el $1^{\circ}$ de mayo y concurrir al mitin de la Federación Obrera en la Plaza Alberdi. Por último, los oficiales peluqueros sometieron a discusión un pliego de condiciones para presentar a los patrones a finales del próximo mes, en el cual reclamaban la jornada máxima de 8 horas y un sueldo mínimo de 3,50 pesos diarios. ${ }^{57}$

Estas consignas no eran datos menores, en la medida que se trataba de una protesta laboral específica presentada por un gremio a la patronal durante la jornada del $1^{\circ}$ de mayo. Además, constituyó la primera evidencia concreta de la decisión de los trabajadores de no laborar durante dicha efeméride. Con el tiempo, la costumbre de no trabajar los primeros de mayos alcanzaría mayor fortaleza y se impondría en el repertorio de prácticas obreras.

\footnotetext{
55 La Gaceta, 2 de mayo de 1914.

56 La Gaceta, 26 de abril de 1914.

$57 \quad$ La Gaceta, 29 de abril de 1914.
} 
La conmemoración del $1^{\circ}$ de mayo de 1915 fue encabezada por la sección tucumana del Partido Socialista Argentino e incluyó una gran manifestación en las plazas de la ciudad y numerosos discursos a cargo de dirigentes locales de renombre como Gregorio R. Pinto quien cerró el acto con palabras alusivas que dejaban claro la adhesión del socialismo tucumano a la Internacional Obrera y, en esa línea, a sus principales proclamas formuladas en el contexto de la Primera Guerra Mundial, que llevó al proletariado universal a protestar enérgicamente "contra el crimen de la guerra, desatado como una maldición sobre los pueblos europeos por la confabulación de los capitalistas, militares y reyes, bendecidos en su infamia por los ministros de la impostura religiosa", según afirmaba Pinto. En ese marco, los manifestantes tucumanos portaron grandes carteles con las leyendas "Viva el $1^{\circ}$ de Mayo", "Trabajadores de todo el mundo uníos" y "Guerra al reino de la guerra", de una de las estrofas del himno de los trabajadores. ${ }^{58}$

La celebración incluyó además una velada en el Teatro Odeón que comenzó con la ejecución de La Marsellesa por parte de la orquesta y continuó con la entonación de Hijos del Pueblo. Posteriormente, el Doctor Manuel Grande Alurralde presentó al delegado del Comité Ejecutivo del partido Socialista enviado para este acto, el Doctor Joaquín Apolinario, quien impartió una conferencia donde abordó los principales aspectos contenidos en el mensaje del gobernador de Tucumán a la Legislatura con motivo del entonces vigente periodo de sesiones y se extendió especialmente en lo relativo a la cuestión azucarera, la educación y los impuestos. ${ }^{59}$

De esta manera, el delegado del partido socialista se refería a tópicos centrales del socialismo argentino que en la época cuestionaba duramente a la política azucarera que consideraba beneficiada por el gobierno nacional a través de los subsidios. Una vez concluida la conferencia, los trabajadores entonaron el Himno de los Trabajadores acompañado por la orquesta, tuvo lugar el sorteo de una rifa y el cuadro filo dramático "Luz y Arte" puso en escena el drama asocial "Las Coyundas", original de Adolfo Bayen y piezas cómicas como "El esquinazo" y "iPobre Toribio!". 60

$58 \quad$ La Gaceta, 2 de mayo de 1916.

59 El Orden, 3 de mayo de 1915 y La Gaceta, 2 de mayo de 1916.

60 La Gaceta, 29 de abril de 1915, y 2 de mayo de 1915. 
Los libertarios, a su vez, prepararon un mitin que tenía previsto partir de la plaza Alberdi y seguir un recorrido por las calles Catamarca, San Juan, Maipú y Chacabuco, hasta concluir en la plaza San Martín. ${ }^{61}$

$\mathrm{Al}$ año siguiente la evocación del Primero de Mayo tuvo la particularidad de incluir un reclamo específico al gobernador de la provincia: la conmutación de la pena al obrero ferroviario Reyes Romero, quien se encontraba preso desde hacía varios años en la penitenciaría acusado de homicidio. Este pedido fue presentado a través de una nota que entregó al mandatario una delegación de los trabajadores en el marco de la manifestación realizada en la plaza Independencia. ${ }^{62}$ Por esa vía comenzaba a delimitarse una práctica nodal y recurrente de las protestas de los trabajadores al poder público. Me refiero no sólo a la manifestación en la plaza Independencia sino también a la modalidad específica de reclamar frente a la casa de Gobierno, epicentro del poder político, al albergar a las principales autoridades de gobierno local.

\section{Consideraciones finales}

En este trabajo analizamos expresiones de sociabilidad y cultura desarrolladas por los trabajadores en Tucumán en un contexto signado por el impulso que adquirió la industrialización basada en la especialización azucarera, la modernización urbana y los adelantos tecnológicos. Tales avances, sin embargo, no se extendieron igualitariamente en la provincia ni beneficiaron a todos los grupos sociales. Mayoritariamente, la clase trabajadora sufrió la dureza de los regímenes laborales y las deficientes condiciones de vida que activaron el vigor del movimiento asociativo y potenciaron la formación del movimiento obrero. En ese marco, y al influjo de las corrientes de izquierda en el mundo del trabajo, como el anarquismo y en especial el socialismo, los centros obreros --como el Centro Cosmopolita de Trabajadores--, conformados mayoritariamente con trabajadores de oficio, motorizaron un conjunto abundante de actividades destinadas al aprovechamiento del tiempo libre, el fomento cultural, el impulso a la educación y la propaganda. En esa dirección, podemos interpretar las veladas literario-musicales compuestas por representaciones

$61 \quad$ La Gaceta, 30 de abril de 1915.

62 La Gaceta, 2 de mayo de 1916 y El Orden, 3 de mayo de 1916. 
teatrales y declamaciones poéticas de contenido social o contestatario, coros e himnos revolucionarios, combinados con números de entretenimiento como rifas y bailes que atraían especialmente al trabajador y a su familia.

Por su parte, también los gremios combinaron sus labores propiamente gremiales con veladas literario musicales y bailes orientados a recaudar fondos para continuar sus esfuerzos dirigidos a conseguir mejoras favorables al sector, mediante las demandas laborales y actividades de promoción a la lectura y la educación. En el caso de las mutuales las necesidades económicas que implicaban las labores de socorro mutuo, como la asistencia médica y la cobertura frente al fallecimiento, así como las obras de infraestructura esenciales de la vida asociativa, tales como la edificación del salón social y la construcción del panteón, alentaron la organización de numerosas fiestas y funciones a beneficio de su caja social.

De esta manera se construyó y modeló un tejido asociativo de sociedades que podían combinar sus funciones específicas con tareas de sociabilidad, educación y cultura. Con lo cual, resulta difícil encasillar a las sociedades en una definición excluyente, ya sea mutual, de recreo, de beneficencia y gremial. Si esta cuestión caracterizó en general al asociacionismo argentino en la época, ${ }^{63}$ un elemento distintivo del mundo asociativo tucumano fue la incidencia de la actividad azucarera y de los conflictos surgidos en torno a dicha industria que contribuyeron a incrementar la formación de centros socialistas en las áreas rurales de la provincia. En ese contexto, se destacó la huelga de peones y jornaleros azucareros de 1904, cuya magnitud y alcance se reflejó en la amplia participación de trabajadores y trabajadoras de los ingenios que a través de las asociaciones liderados por el socialismo protestaron para alcanzar mejoras laborales capaces de revertir las dramáticas condiciones de vida y de trabajo imperantes en la industria azucarera.

63 A su vez, la breve duración de algunas sociedades que se formaban y rápidamente dejaban de existir, las escisiones y fusiones de asociaciones, así como la dificultad para localizar fuentes de las sociedades fueron otros rasgos del mundo asociativo. Al respecto, Hernán Otero, "El asociacionismo francés en la Argentina. Una perspectiva secular", en EIAL vol.21, n. ${ }^{\circ} 2$, Tel-Aviv, Universidad de Tel-Aviv, 2010, pp.123-150. De la abundante bibliografía sobre el asociacionismo de los trabajadores en otros países de América Latina nos apoyamos especialmente en los análisis de Sergio Grez Toso, "La trayectoria histórica del mutualismo en Chile (1853-1990). Apuntes para su estudio", en Mapocho n. ${ }^{\circ}$ 35, Santiago de Chile, biblioteca Nacional de Chile, 1994, pp.293-315, Sonia Pérez Toledo, Los hijos del trabajo. Los artesanos de la ciudad de México, 1780-1853, México, UAM-Iztapalapa/El Colegio de México, 1996 y Carlos Illades, Hacia la República del trabajo en México, 1853-1876, México, UAM-Iztapalapa/El Colegio de México, 1996. 
Por último, interesa sugerir que dentro del repertorio de expresiones de sociabilidad y cultura de los trabajadores se destacó la celebración de rituales como el $1^{\mathrm{o}}$ de mayo, entendida como la principal conmemoración obrera e impulsada fuertemente por el socialismo. Tal como sucedía en distintas regiones y provincias del país, los militantes y dirigentes obreros organizaron celebraciones del Primero de Mayo que reunían dos grandes momentos, la manifestación en calles y plazas y la realización de veladas literario-musicales en los locales de los centros de trabajadores.

En dichas fiestas el repertorio característico de la cultura obrera afín al socialismo alcanzaba un gran protagonismo a través de la ejecución y entonación de himnos y coros revolucionarios, la representación de dramas sociales y el dictado de conferencias que sintetizaban las principales consignas socialistas. Estas presentaciones se combinaban con entretenimientos como rifas y bailes, capaces de concitar la atención de los trabajadores y sus familias.

A su vez, la ocupación de los espacios públicos por parte de los trabajadores que recorrían los puntos neurálgicos de la ciudad servía para visibilizar sus demandas y exhibir la fuerza y la organización del movimiento obrero. En este aspecto, interesa agregar la disputa que enfrentaba a los socialistas y anarquistas que competían por la organización y el liderazgo en el mundo del trabajo. Este enfrentamiento se reflejó especialmente durante las conmemoraciones del Primero de Mayo que, gradualmente, fue objeto de mítines separados por parte del socialismo y del anarquismo, corrientes que a través de sus dirigentes movilizaron a los trabajadores, tanto de la ciudad de San Miguel de Tucumán como de algunas localidades del interior de la provincia. En ese sentido, frente al antiguo predominio del socialismo en el movimiento obrero tucumano, la difusión del anarquismo avanzó especialmente en algunos gremios y asociaciones de la capital provincial --como en la sociedad de oficiales peluqueros y el sindicato de mozos-- y entre los trabajadores de los Talleres Ferroviarios de Tafí Viejo. 


\section{Bibliografía}

\section{Fuentes primarias}

\section{Archivos:}

Archivo Histórico de Tucumán (AHT), Sección Administrativa (SA), Año 1894, Vol. 206.

Biblioteca Popular Obrera "María Lisa Buffo de Ferro" (BPO. BF.) Comisiones Directivas, Años: 1899-1908.

\section{Publicaciones periódicas}

Germinal, 1908.

La Estrella del Norte, 1905.

La Gaceta, 1912-1916.

La Vanguardia, 1897-1908.

El Nacional, 1901.

El Orden, 1897-1916.

El Tipógrafo, 1907.

\section{Fuentes secundarias}

Agulhon, Maurice, El Círculo burgués. La sociabilidad en Francia, 1810-1848, Buenos Aires, Siglo XXI editores, 2009, p. 43.

Bilbao, Santiago, "Anarquismo en el noroeste a principio del siglo xx: Germinal, publicación tucumana”, en Estudios del Trabajo n. ${ }^{\circ 28}$, Buenos Aires, ASET, 2004, pp.143151.

Bilhão, Isabel “"Dia de festa, dia de luto ou feriado nacional? As diferentes concepções do Primero de Maio no Brasil ao longo dos anos 1929", en Hib, Revista de Historia Iberoamericana vol.6, n. ${ }^{\circ}$, Santiago de Chile, Universia, 2013, pp.29-52.

Bravo, María Celia, "Liberales, Socialistas, Iglesia y Patrones frente a la situación de los Trabajadores en Tucumán (1880-1910)”, en Juan Suriano, (comp.), La cuestión social en Argentina, 1870-1943, Buenos Aires, La Colmena, 2004, pp. 31-61.

Bravo, María Celia y Teitelbaum, Vanesa, "Socialistas y católicos disputando el mundo los trabajadores. Protesta, sociabilidad y política en Tucumán (1895-1910)”, en Entrepasados. Revista de Historia, $\mathrm{N}^{0} 35$, comienzos de 2009, Buenos Aires.

Bravo, María Celia y Teitelbaum, Vanesa, "El mutualismo y la compleja relación con el gremialismo (Tucumán, 1877-1914)”, en Bravo, María Celia y Fernández Sandra, Formando el espacio público, en María Celia Bravo y Sandra Fernández, Formando 
el espacio público. Asociacionismos y política. Siglos XIX y XX, Tucumán, Editorial de la Universidad Nacional de Tucumán, 2014, pp. 57-77.

Camarero, Hernán, A la conquista de la clase obrera. Los comunistas y el mundo del trabajo en la Argentina, 1920-1935, Buenos Aires, Siglo XXI, 2007.

Campi, Daniel, "Captación forzada de mano de obra y trabajo asalariado en Tucumán, 1856-1896”, Anuario IEHS, No 8, Universidad Nacional del Centro de la Provincia de Buenos Aires, Tandil, 1993.

Campi, Daniel, Azúcar y trabajo. Coacción y mercado laboral. Tucumán, 1856-1896, Tesis doctoral (Inédita), Universidad Complutense de Madrid, 2002.

Casanovas Codina, Joan, "El artesanado habanero y los orígenes del Círculo de Trabajadores", Historia Social $n^{\circ}$ 31, Valencia, Centro de la UNED Alzira-Valencia, Instituto de Historia Social, Fundación Historia Social, 1998.

Falcón, Ricardo, El mundo del trabajo urbano (1890-1914), Buenos Aires, Centro Editor de América Latina, 1986, pp. 91-92.

Falcón, Ricardo, Los orígenes del movimiento obrero (1857-1899), Buenos Aires, Centro Editor de América Latina, 1984.

Falcón, Ricardo, El mundo del trabajo urbano (189o-1914).

Falcón, Ricardo, La Barcelona Argentina, Rosario, Laborde editor, 2005.

Fernández, María Estela, "Las políticas de salud: el caso de los hospitales en Tucumán a fines del siglo XIX”, X Jornadas Interescuelas/Departamentos de Historia, Rosario, 20 al 23 de septiembre, 2005.

Grez Toso, Sergio, "La trayectoria histórica del mutualismo en Chile (1853-1990). Apuntes para su estudio", en Mapocho n. ${ }^{\circ} 35$, Santiago de Chile, biblioteca Nacional de Chile, 1994, pp.293-315.

Gutiérrez, Leandro H. y Romero, Luis Alberto, Sectores populares, cultura y política. Buenos Aires en la entreguerra, Buenos Aires, Sudamericana, 1995.

Hobsbawm, Eric y Rudé, George, Revolución Industrial y revuelta agraria. El capitán Swing, Madrid, Siglo XXI, 1978.

Hobsbawm, Eric, Gente poco corriente. Resistencia, rebelión y jazz, Barcelona, Crítica, 1999.

Iñigo Carrera, Nicolás, "La historia de los trabajadores", en Jorge Gelman (comp.), La historia económica en la encrucijada, Buenos Aires, Prometeo, 2006.

Kocka, Jürgen, "Los artesanos, los trabajadores y el Estado: hacia una historia social de los comienzos del movimiento obrero alemán", Historia Social No 12, Valencia, Centro de la UNED Alzira-Valencia, Instituto de Historia Social, Fundación Historia Social, 1992, pp. 101-118.

Lobato, Mirta Zaida, La prensa obrera, Buenos Aires, Edhasa, Temas de la Argentina, 2009. 
Lobato, Mirta y Suriano, Juan, "Trabajadores y movimiento obrero: entre la crisis y la profesionalización del historiador", en Entrepasados año III, n. ${ }^{\circ} 4-5$, Buenos Aires, Universidad de Buenos Aires, 1993, pp.41-64.

Lobato, Mirta Zaida y Palermo, Silvana Alejandra, "Del trabajo a las calles: dignidad, respeto y derechos para los y las trabajadoras”, en Mirta Zaida Lobato (Editora), Buenos Aires. Manifestaciones, fiestas y rituales en el siglo XX, Buenos Aires, Biblos, 2011, pp. 45-74.

Mases, Enrique, "El tiempo libre de los trabajadores en la norpatagonia. De la cultura política, las prácticas recreativas y deportivas al disciplinamiento social 1900-1945”, en Quinto Sol no 9-10, Santa Rosa, Universidad Nacional de La Pampa, 2005-2006, pp.73-97.

Morales Muñoz, Manuel, "Un espacio propio. Sociabilidad e identidad obrera en Andalucía”, Historia Social, $\mathrm{N}^{\circ}$ 56, 2006, Valencia, Centro de la UNED Alzira-Valencia, Instituto de Historia Social, pp. 53-69.

Morales Muñoz, Manuel, "Los trabajadores de oficio en la construcción del socialismo español”, en Vicent Sanz Rosalén y José Antonio Piqueras, En el nombre del oficio. El trabajador especializado: corporativismo, adaptación y protesta, Madrid, Biblioteca Nueva, 2005.

Otero, Hernán, "El asociacionismo francés en la Argentina. Una perspectiva secular", en EIAL vol.21, n. ${ }^{\circ}$ 2, Tel-Aviv, Universidad de Tel-Aviv, 2010, pp.123-150.

Rudé, George, La multitud en la historia. Los disturbios populares en Francia e Inglaterra, 1730-1848, Madrid, Siglo XXI, 1979.

Rudé, George, Revuelta popular y conciencia de clase, Barcelona, Crítica, Grijalbo, 1981.

Sabato, Hilda, “Capítulo 2/1860-1920, Estado y sociedad civil”, en Elba Luna y Elida Cecconi (coords.), De las cofradías a las organizaciones de la sociedad civil. Historia de la iniciativa asociativa en Argentina, 1776-1990, Buenos Aires, Edilab Editora, 2002, pp.99-167.

Suriano, Juan, Anarquistas. Cultura y política libertaria en Buenos Aires, 1890-191o, Buenos Aires, Ediciones Manantial, 2001.

Suriano, Juan, “El largo camino hacia la ciudadanía social”, en Susana Torrado (comp.), Población y bienestar en la Argentina del primero al segundo Centenario. Una historia social del siglo $X X$, Tomo I, Buenos Aires, Serie Estudios del Bicentenrio, Edhasa, 2007, pp.67-95.

Teitelbaum, Vanesa, "El mutualismo en el mundo del trabajo (Tucumán, Argentina, 18771914)", en Varia Historia vol.27, n. ${ }^{\circ} 46$, Belo Horizonte, Universidade de minas Gerais, 2011, pp.665-688.

Teitelbaum, Vanesa, "Contra la tiranía del mostrador. La campaña de la prensa y los trabajadores por el descanso dominical en Tucumán del entre-siglo”, en Anuario de Estudios Americanos, vol.68, n. ${ }^{\circ}$, Sevilla, EEHA, 2011, pp.223-252.

Teitelbaum, Vanesa, El Centro Cosmopolita de Trabajadores: un espacio de referencia del

Dossier: Artesanos: formas de trabajo, sociabilidades, movilidad social y cultura política en Hispanoamérica, siglos XVI-XX 
movimiento obrero en el norte argentino en los umbrales del siglo Xx", en Estudios Sociales año XXI, n. ${ }^{\circ}$ 40, Santa Fe, Universidad Nacional del Litoral, 2011, pp.145174.

Teitelbaum, Vanesa, "Los centros obreros como ámbitos de cultura, protesta y política (Tucumán, 1895-1910)", en AA. VV., La clase obrera y el Centenario-1910-trabajos de investigación, Central de Trabajadores de la Argentina Ediciones, 2011, pp.71-112.

Teitelbaum, Vanesa, "Protección, cultura y sociabilidad: El Centro de Trabajadores de Socorros Mutuos de Monteros, (Tucumán, Argentina, 1890-1913)”, Encuentros Latinoamericanos n. ${ }^{\circ}$ 14, Montevideo, Universidad de la República, 2012.

Thompson, Edward P., La formación de la clase obrera en Inglaterra tomo 1, Barcelona, Editorial Crítica, 1989 y Tradición, revuelta y conciencia de clase, Estudios sobre la crisis de la sociedad preindustrial, Barcelona, Crítica, 1979.

Torre, Juan Carlos, "Acerca de los estudios sobre la historia de los trabajadores en Argentina”, Anuario IEHS V, Tandil, Instituto de Estudios Histórico-Sociales, Facultad de Ciencias Humanas, Universidad Nacional del Centro, 1990.

Viguera, Aníbal, "El primero de mayo en Buenos Aires, 1890-1950: evolución y usos de una tradición", en Boletín del Instituto de Historia Argentina y Americana "Dr. E. Ravignani”, Tercera Serie, n. ${ }^{\circ}$ 3, Buenos Aires, Universidad de Buenos Aires, 1991, pp.57-6o. 